Article

\title{
Synthesis of Silicon Carbide Powders from Methyl-Modified Silica Aerogels
}

\author{
Kyoung-Jin Lee ${ }^{1}$, Yanggu Kang ${ }^{1,2}$, Young Hun Kim ${ }^{3}$, Se Won Baek ${ }^{3}$ and Haejin Hwang ${ }^{1, *}$ \\ 1 Department of Materials Science and Engineering, Inha University, 100 Inha-ro, Incheon 22212, Korea; \\ legna211@naver.com (K.-J.L.); kykang1006@komexcarbon.co.kr (Y.K.) \\ 2 KOMEX, Ansung, Gyeonggi 17604, Korea \\ 3 Basic Materials \& Chemicals R\&D, LG Chem, 188 Munji-ro, Yuseong-gu, Daejeon 34122, Korea; \\ zerok@lgchem.com (Y.H.K.); hector@lgchem.com (S.W.B.) \\ * Correspondence: hjhwang@inha.ac.kr; Tel.: +82-32-860-7521
}

Received: 3 August 2020; Accepted: 3 September 2020; Published: 4 September 2020

\begin{abstract}
SiC}$ ) powders were synthesized by the carbothermal reduction of methyl-modified silica aerogel/carbon mixtures. The correlations between the phase evolution and morphologies of the $\mathrm{SiC}$ powders and the $\mathrm{C} / \mathrm{SiO}_{2}$ ratio were investigated. At a $\mathrm{C} / \mathrm{SiO}$ ratio of $3, \beta-\mathrm{SiC}$ formed at $1425^{\circ} \mathrm{C}$ and single-phase $\mathrm{SiC}$ powders were obtained at $1525^{\circ} \mathrm{C}$. The methyl groups $\left(-\mathrm{CH}_{3}\right)$ on the silica aerogel surfaces played important roles in the formation of $\mathrm{SiC}$ during the carbothermal reduction. SiC could be synthesized from the silica aerogel/carbon mixtures under lower temperature and $\mathrm{C} / \mathrm{SiO}_{2}$ ratios than those needed for quartz or hydrophilic silica. The morphology of the SiC powder depended on the $\mathrm{C} / \mathrm{SiO}_{2}$ ratio. A low $\mathrm{C} / \mathrm{SiO}_{2}$ ratio resulted in $\beta-\mathrm{SiC}$ powder with spherical morphology, while agglomerates consisting of fine $\mathrm{SiC}$ particles were obtained at the $\mathrm{C} / \mathrm{SiO}_{2}$ ratio of 3. High-purity $\mathrm{SiC}$ powder (99.95\%) could be obtained with $\mathrm{C} / \mathrm{SiO}_{2}=0.5$ and 3 at $1525{ }^{\circ} \mathrm{C}$ for $5 \mathrm{~h}$.
\end{abstract}

Keywords: silicon carbide $(\mathrm{SiC})$; silica $\left(\mathrm{SiO}_{2}\right)$; aerogel; surface methyl $\left(-\mathrm{CH}_{3}\right)$ group; carbothermal reduction

\section{Introduction}

Silicon carbide $(\mathrm{SiC})$ is a typical non-oxide ceramic material that forms covalent bonds in structural units. Because of its strong covalent bonds and chemical stability, SiC exhibits excellent properties at temperatures up to $1400^{\circ} \mathrm{C}$ such as a high hardness, wear resistance, corrosion resistance, and strength [1,2]. Other notable features of $\mathrm{SiC}$ are high thermal and electrical conductivities. Based on these excellent mechanical and electronic properties, $\mathrm{SiC}$ has been actively studied in various fields with respect to different applications such as for gas turbine components, heat exchangers, high temperature gas filters, power devices, heat dissipation substrates, and catalyst support materials.

The SiC ceramics can be fabricated by sintering SiC powders or preceramic polymers [3-5] at high temperature because of the covalent nature of the Si-C bond and low self-diffusion coefficient [6]. Single crystals of $\mathrm{SiC}$ for power device applications can be grown from $\mathrm{SiC}$ powder compacts by physical vapor transport (PVT) or sublimation epitaxial growth (SEG) $[7,8]$. The defects (stacking faults and dislocations) in SiC single crystals, sinterability, microstructure, and properties of sintered SiC strongly depend on the purity, morphology, size, and distribution of the SiC starting powders [9-12].

Various techniques have been developed for the synthesis of high-quality $\mathrm{SiC}$ powders such as the carbothermal reduction of silica $\left(\mathrm{SiO}_{2}\right)$ [13-15], direct carbonization [16,17], the thermal decomposition of preceramic polymers [18], and chemical vapor deposition (CVD) $[19,20]$. The synthesis of $\alpha-\operatorname{SiC}$ using the carbothermal reduction of $\mathrm{SiO}_{2}$ is the most common technique, which is characterized by 
relatively low-cost processing (inexpensive starting materials) and can be easily scaled up [21,22]. The carbothermal reaction can be expressed as follows:

$$
\mathrm{SiO}_{2}(\mathrm{~s})+3 \mathrm{C}(\mathrm{s}) \rightarrow \mathrm{SiC}(\mathrm{s})+2 \mathrm{CO}(\mathrm{g})
$$

A C/SiO 2 powder mixture with a stoichiometric $\mathrm{C} / \mathrm{SiO}_{2}$ ratio above 3 is required for the reaction to obtain $\mathrm{SiO}_{2}$-free $\mathrm{SiC}$ powder [23]. Because gaseous silicon monoxide ( $\mathrm{SiO}$ ) species may form and the $\mathrm{SiC}$ particles grow based on the reaction of $\mathrm{SiO}$ and $\mathrm{C}$ [24], the morphology and characteristics of the $\mathrm{SiC}$ powder obtained using carbothermal reduction strongly depend on starting the starting material, that is, $\mathrm{SiO}_{2}$ and $\mathrm{C}$, as well as on the reaction conditions.

Parmentier et al. synthesized SiC powders with high specific surface areas through the carbothermal reaction of mesoporous MCM-48 silica and pyrolytic carbon using the chemical vapor infiltration of propylene [25]. Meng et al. proposed a novel sol-gel process to obtain $\mathrm{SiO}_{2}$ xerogels containing carbon nanoparticles [26]. They fabricated nanostructured $\alpha$-SiC powder at $1650{ }^{\circ} \mathrm{C}$ using the carbothermal reduction of the precursor powder mentioned above.

In our previous study [27], we developed a novel technique for the synthesis of silica aerogel powders with spherical shapes using emulsion polymerization from water glass. The synthesized silica aerogels were highly porous ( $\sim 95 \%$ porosity), and their surfaces were modified to contain methyl groups $\left(-\mathrm{CH}_{3}\right)$. When the surface-modified silica aerogel is employed as a starting material for the carbothermal reduction to synthesize $\mathrm{SiC}$ powder, the covalent bonds of $\mathrm{Si}-\mathrm{C}$ and the high surface energy, owing to mesoporous nature of the silica aerogels, can accelerate the conversion of silica to $\mathrm{SiC}$. In addition, the use of the surface-modified silica aerogel is expected to produce a spherical SiC powder. To our knowledge, there has been no attempt to use silica aerogels containing surface methyl groups to synthesize $\mathrm{SiC}$ powder.

This study focuses on the synthesis of spherical $\beta$-SiC powders through the carbothermal reduction of surface-modified $\mathrm{SiO}_{2}$ aerogels. The effects of the surface methyl groups $\left(-\mathrm{CH}_{3}\right)$ and mesoporous structure of the silica aerogel on the carbothermal reduction reaction were investigated for different $\mathrm{SiO}_{2} / \mathrm{C}$ ratios. The synthesized $\mathrm{SiC}$ powders were characterized by X-ray diffraction (XRD) and scanning electron microscopy (SEM).

\section{Materials and Methods}

\subsection{Preparation of Silica Aerogel}

Silica aerogel and carbon black (Raven425, Birla Carbon, Seoul, Korea) were used as starting materials for the carbothermal reduction. Silica aerogel powders were prepared from water glass (silica content, 28-30 wt.\%; $\mathrm{SiO}_{2} / \mathrm{Na}_{2} \mathrm{O}=3.52: 1$; Young IL Chemical, Incheon, Korea) and n-hexane (95\%, Samchun Pure Chemicals, Pyeongtaek, Korea) using an emulsion polymerization technique. The detailed procedure is described elsewhere [27]. Silica aerogel and carbon black were mixed in n-hexane using an ultrasonic bath. Homogeneous slurry was obtained after $10 \mathrm{~min}$ and dried at $100{ }^{\circ} \mathrm{C}$ in an electric oven. The $\mathrm{C} / \mathrm{SiO}_{2}$ molar ratios were $0,0.5,1,2$, and 3. The $\mathrm{SiO}_{2} / \mathrm{C}$ powder mixture was poured into an alumina $\left(\mathrm{Al}_{2} \mathrm{O}_{3}\right)$ boat, which was placed inside a tube furnace under a constant argon flow $(100 \mathrm{sccm})$. The carbothermal reduction was performed at $1450-1525^{\circ} \mathrm{C}$ for 1 and $5 \mathrm{~h}$. The synthesized powders were further heat-treated at $800^{\circ} \mathrm{C}$ for $1 \mathrm{~h}$ in air to remove residual carbon black.

\subsection{Evaluation}

To measure tap density, $0.2 \mathrm{~g}$ of the silica aerogel powder was placed in a $5 \mathrm{~mL}$ cylinder $(9 \mathrm{~mm}$ in diameter) and tapped 1000 times using a tapping density tester (TAP-2S, Logan Instruments Co., Somerset, NJ, USA). Fourier transform infrared (FT-IR) spectroscopy (FTS-165, Bio-Rad, Hercules CA, USA) was used to confirm the surface chemical structure of the aerogels in the wave number range of $400-4000 \mathrm{~cm}^{-1}$. The powder was mixed with potassium bromide $(\mathrm{KBr})$ and pressed to form a sample 
disk for FT-IR measurements. The phases of the obtained powders were identified using XRD (D/MAX 2200V/PC, RIGAKU Co., Ltd., Tokyo, Japan) with Ni-filtered CuK $\alpha$ radiation. The thermogravimetry (TG) and differential thermal analysis (DTA) (Diamond TG/DTA Lab System, Perkin Elmer) was performed in air up to $800^{\circ} \mathrm{C}$ at a heating rate of $5{ }^{\circ} \mathrm{C} \cdot \mathrm{min}^{-1}$ to investigate the thermal behavior of the silica aerogel powder. The carbon, hydrogen, and oxygen contents in the starting silica aerogel and synthesized $\mathrm{SiC}$ powders were determined using an elemental analyzer (EA, Thermo EA1112, Thermo Fisher Scientific, Waltham, MA, USA) and an oxygen-nitrogen analyzer (EMGA-920, Horiba, Japan), respectively. The surface area, pore volume, and mean pore size of the starting silica aerogel powder were measured using Brunauer-Emmett-Teller (BET) equipment $(0.01<\mathrm{p} / \mathrm{p} 0<1$; ASAP 2010; Micrometrics, Norcross, GA, USA). The equipment is used to measure the amount of nitrogen that is adsorbed as the pressure changes. Before $\mathrm{N}_{2}$ adsorption, the powder sample was degassed at $200{ }^{\circ} \mathrm{C}$. The microstructures of the obtained powder samples were examined using field-emission SEM (FESEM, S-4300, Hitachi, Japan).

\section{Results and Discussion}

Some of the physical properties of the starting silica aerogel powder are listed in Table 1. The silica aerogel has a highly porous structure with mesopores, and its surface was modified by methyl groups $\left(-\mathrm{CH}_{3}\right)$. The Fourier transform infrared spectra of the starting silica aerogel powder are shown in Figure 1 . The absorption peaks near 1100,800 , and $460 \mathrm{~cm}^{-1}$ were assigned to the asymmetry, symmetry, and bending modes of Si-O-Si, respectively [28,29]. These peaks are characteristic peaks showing a typical silica aerogel network structure. By contrast, the peaks at 1260 and $850 \mathrm{~cm}^{-1}$ indicate the presence of a Si-C bond, while the peaks at 2900 and $1450 \mathrm{~cm}^{-1}$ are due to $\mathrm{C}-\mathrm{H}$ stretching [30,31]. Thus, it can be inferred that the silica aerogel was modified into a hydrophobic form by the surface methyl groups $\left(-\mathrm{CH}_{3}\right)$. A $\mathrm{N}_{2}$ adsorption-desorption isotherm of the starting silica aerogel powder is shown in Figure 2. $\mathrm{N}_{2}$ absorption sharply increases near the high relative pressure (Type IV adsorption-desorption isotherm), which indicates that the silica aerogel is mesoporous [32,33].

Table 1. Some physical properties of the starting silica aerogel powder.

\begin{tabular}{lccccc}
\hline & $\begin{array}{c}\text { Tap Density, } \\
\mathbf{g} \cdot \mathbf{c m}^{-\mathbf{3}}\end{array}$ & $\begin{array}{c}\text { Porosity, } \\
\mathbf{\%} \S\end{array}$ & $\begin{array}{c}\text { BET Surface Area, } \\
\mathbf{m}^{\mathbf{2}} \cdot \mathbf{g}^{-\mathbf{1}}\end{array}$ & $\begin{array}{c}\text { Pore Volume, } \\
\mathbf{c m}^{\mathbf{3}} \cdot \mathbf{g}^{-\mathbf{1}}\end{array}$ & $\begin{array}{c}\text { Pore Diameter, } \\
\mathbf{n m}\end{array}$ \\
\hline Silica aerogel & 0.12 & 94.5 & 730 & 2.35 & 12.89 \\
\hline \multicolumn{6}{c}{$\S$ porosity $=\left((1-\right.$ tap density $\left.) / \rho_{\mathrm{SiO} 2}\right) \times 100, \rho_{\mathrm{SiO} 2}=2.19 \mathrm{~g} \cdot \mathrm{cm}^{-3} \cdot$}
\end{tabular}

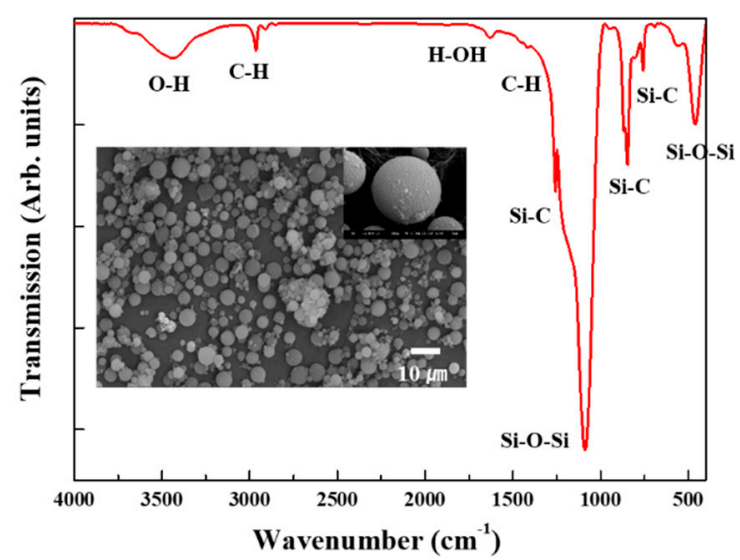

Figure 1. FT-IR spectra of the starting silica aerogel powder. The inset is an SEM image of the starting silica aerogel powder. 

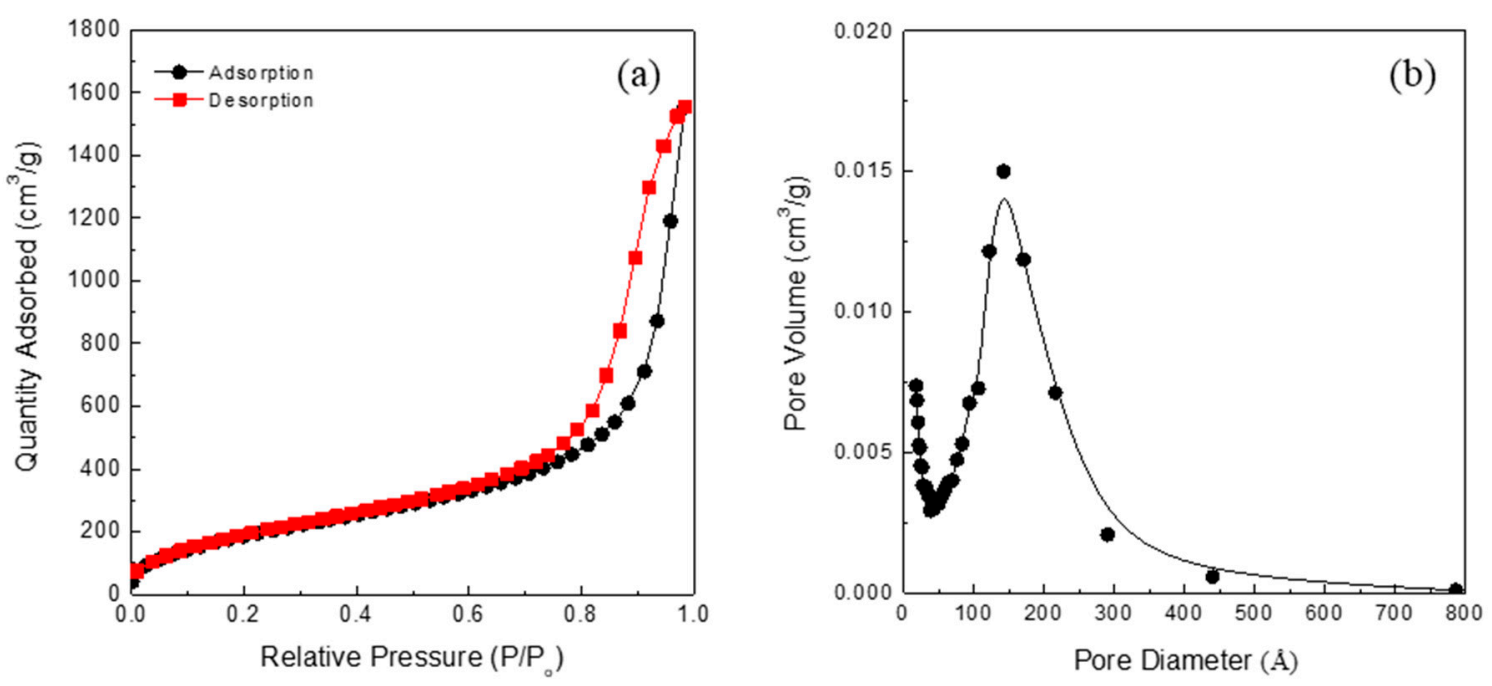

Figure 2. $\mathrm{N}_{2}$ adsorption-desorption isotherm (a) and pore size distribution of the starting silica aerogel powder (b).

The TG was carried out to quantitatively analyze the presence and content of surface carbon in the silica aerogel powder. The TG curves are illustrated in Figure 3. Weight loss was observed in two temperature regions. The weight loss of $\sim 0.5 \%$ observed from room temperature to $200{ }^{\circ} \mathrm{C}$ is due to the release of physically adsorbed water or the evaporation of residual solvents on the surface of the silica aerogel. On the other hand, the weight loss of $11.8 \%$ in the temperature range of 300 to $800{ }^{\circ} \mathrm{C}$ is due to the combustion of the surface methyl group $\left(-\mathrm{CH}_{3}\right)$. It is assumed that the DTG peak and sharp weight loss at $\sim 475^{\circ} \mathrm{C}$ can be attributed to the oxidation of the surface methyl groups $\left(-\mathrm{CH}_{3}\right)$ of hydrophobic silica aerogel particles [34]. The silica aerogel, which is chemically modified by surface methyl groups, exhibits a hydrophobic-hydrophilic transition upon heating in air, which is due to the oxidation of $-\mathrm{CH}_{3}$. The EA analysis revealed that the carbon and hydrogen contents of the silica aerogel powder were 11.78 and $3.04 \mathrm{wt} . \%$, respectively. This value $(11.78 \mathrm{wt} . \%$ of carbon) corresponds to $\sim 0.70 \mathrm{~mol} \%$ of $\mathrm{SiO} 2$. Therefore, the actual $\mathrm{C} / \mathrm{SiO}_{2}$ ratios are $0.70,1.30,1.88,3.06$, and 4.23 for the nominal $\mathrm{C} / \mathrm{SiO}_{2}$ ratios of $0,0.5,1,2$, and 3 , respectively.

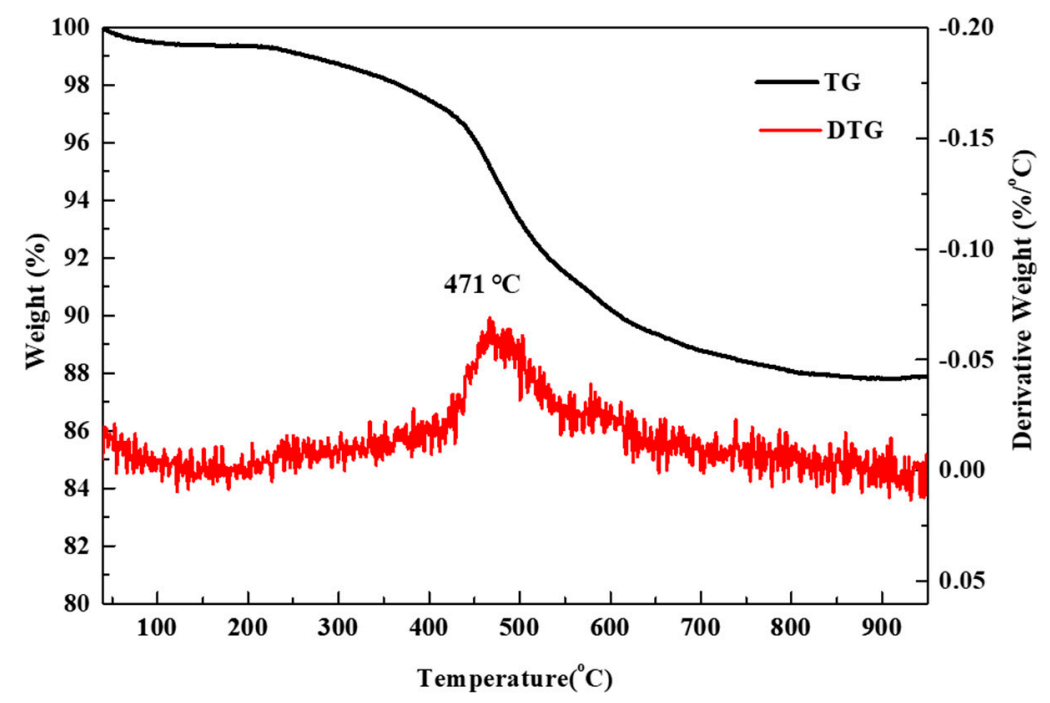

Figure 3. TG and its derivative curves for the silica aerogel powder.

Figure 4 illustrates the XRD patterns of the powder samples synthesized from $\mathrm{SiO}_{2}-\mathrm{C}$ mixtures with various $\mathrm{C} / \mathrm{SiO}_{2}$ ratios at $1525{ }^{\circ} \mathrm{C}$ for $1 \mathrm{~h}$. The powder samples obtained at $\mathrm{C} / \mathrm{SiO}_{2}$ ratios of 0 and 0.1 are $\alpha$-cristobalite that formed from amorphous silica. This indicates that the carbothermal 
reduction did not proceed under these two conditions. This is reasonable because the $\mathrm{C} / \mathrm{SiO}_{2}$ ratios of 0 and 0.1 are much lower than the stoichiometric value (3). On the other hand, in the powder sample synthesized from the $\mathrm{SiO}_{2}-\mathrm{C}$ mixture with a $\mathrm{C} / \mathrm{SiO}_{2}$ ratio of 0.3 , the $\alpha$-cristobalite peak intensity was decreased and peaks corresponding to $\beta-\mathrm{SiC}$ appeared. At a $\mathrm{C} / \mathrm{SiO}_{2}$ ratio of 0.5 , all peaks due to $\alpha$-cristobalite disappeared and single-phase $\beta$-SiC powder was obtained. Three peaks $\left(35.5^{\circ}, 41.5^{\circ}\right.$, and $\left.59.9^{\circ}\right)$ are attributable to various $\beta-\mathrm{SiC}$ facets, and the small peak observed at $34.0^{\circ}$ is due to stacking faults in $\beta-\mathrm{SiC}$. This result is unexpected because the $\mathrm{C} / \mathrm{SiO}_{2}$ ratio of 0.5 is also much lower than the stoichiometric ratio required for the carbothermal reduction of silica. Generally, a $\mathrm{C} / \mathrm{SiO}_{2}$ ratio above the stoichiometric value is required for the carbothermal reduction of silica $[14,23,26]$. Thus, the result observed in Figure 4 strongly suggests that the surface methyl groups, which modify the silica aerogel particles, represent an efficient carbon source for the carbothermal reduction.

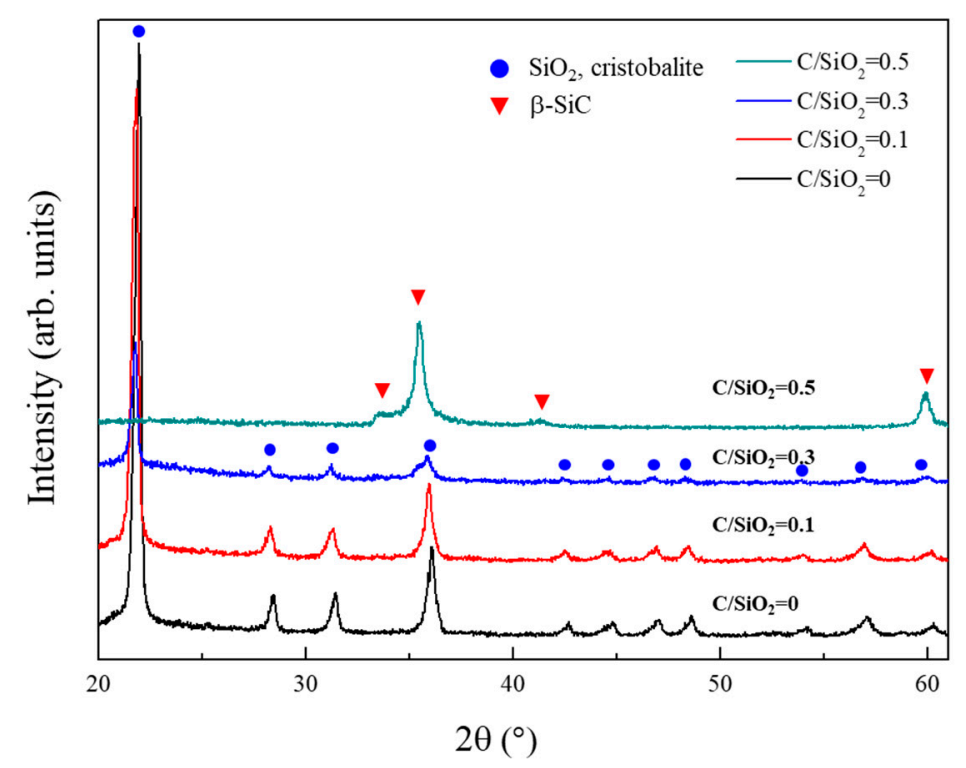

Figure 4. XRD patterns of the powder samples synthesized under various $\mathrm{C} / \mathrm{SiO}_{2}$ ratios at $1525{ }^{\circ} \mathrm{C}$.

Figure 5 illustrates the XRD patterns of the powder samples synthesized from the $\mathrm{SiO}_{2}-\mathrm{C}$ mixture with a $\mathrm{C} / \mathrm{SiO}_{2}$ ratio of 0.5 at various reduction temperatures for $1 \mathrm{~h}$. At $1450{ }^{\circ} \mathrm{C}$, the powder sample consists of $\beta$-SiC and $\alpha$-cristobalite. As the reduction temperature increases, the peak intensity of $\alpha$-cristobalite gradually decreases, while that of $\beta$-SiC increases. Based on Figure 5 , it can be inferred that a reduction at $1525^{\circ} \mathrm{C}$ is required to synthesize a single-phase $\beta-\mathrm{SiC}$ at a $\mathrm{C} / \mathrm{SiO}_{2}$ ratio of 0.5 .

We calculated the equilibrium compositions for the carbothermal reduction reaction as a function of temperature in a previous study. The results indicated that $\beta$-SiC forms at temperatures above $1516{ }^{\circ} \mathrm{C}$ [35]. Based on the XRD analysis (Figure 5), $\beta$-SiC formed at $1450{ }^{\circ} \mathrm{C}$, which is $\sim 70{ }^{\circ} \mathrm{C}$ lower than the temperature obtained from the thermodynamic calculation $\left(1516^{\circ} \mathrm{C}\right)$. This discrepancy can be attributed to the enhanced reactivity between silica and carbon or the increased surface energy (nano-size effect) [36,37]. In this study, surface methyl groups are the carbon source, which are bonded to the silica aerogels at the atomistic level. Therefore, it can be expected that the carbothermal reaction proceeds in a highly reactive state. In addition, the high mesopore volume and high specific surface area of the silica aerogels allow the nano-size effect on the conversion of silica to SiC [25]. The thermodynamic calculation of the carbothermal reduction of silica considering the surface energy contribution indicates that the formation temperature for $\mathrm{SiC}$ can be reduced to $1410^{\circ} \mathrm{C}$ [35].

To confirm that the surface methyl groups of the silica aerogel were the carbon source for the carbothermal reduction of silica, the surface methyl groups were removed by calcining the silica aerogel at $600{ }^{\circ} \mathrm{C}$ for $3 \mathrm{~h}$ in air. The resulting hydrophilic silica aerogel powder was mixed with carbon black, and the carbothermal reduction was performed as described in Section 2. For comparison, 
a commercial quartz powder was purchased from Junsei (extra pure, Japan) and used for an additional carbothermal reduction experiment.

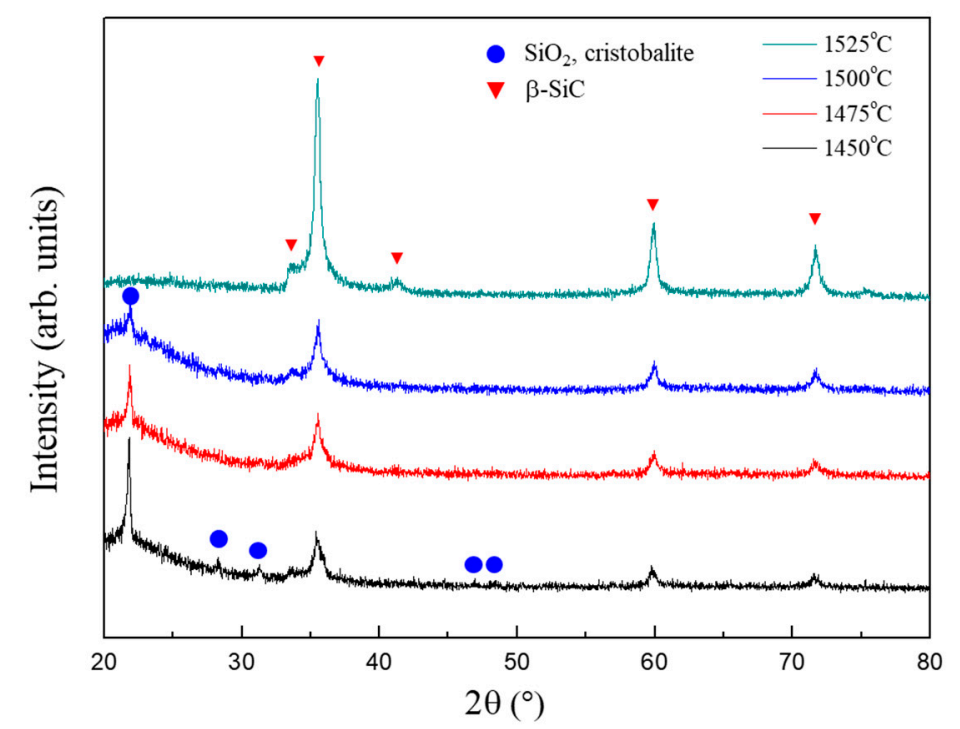

Figure 5. XRD patterns of the powder samples synthesized from the $\mathrm{SiO}_{2}-\mathrm{C}$ mixtures with the $\mathrm{C} / \mathrm{SiO}_{2}$ ratio of 0.5 at various reduction temperatures.

Figure 6 illustrates the XRD patterns of the powder samples synthesized from the hydrophobic silica aerogel, aerogel without surface methyl groups (hydrophilic silica aerogel), and quartz powders. The carbothermal reductions of the hydrophobic silica aerogel (Figure $6 \mathrm{a}, \mathrm{b}$ ) and other samples (Figure $6 \mathrm{c}, \mathrm{d}$ ) were performed at 1525 and $1550{ }^{\circ} \mathrm{C}$, respectively. As described above, the powder sample synthesized from the hydrophobic silica aerogel containing surface methyl groups was single-phase $\beta$-SiC, although the $\mathrm{C} / \mathrm{SiO}_{2}$ ratio was 0.5 and the reduction temperature was $1525^{\circ} \mathrm{C}$. By contrast, the XRD analysis indicates that the powder sample synthesized from the hydrophilic silica aerogel is $\alpha$-cristobalite. Characteristic peaks corresponding to the crystalline $\beta$-SiC phase could not be observed. This phenomenon suggests that the surface methyl groups play important roles in the enhancement of the carbothermal reduction reaction of silica. With respect to quartz, $\alpha$-cristobalite remained in the synthesized powder, although the reduction temperature and $\mathrm{C} / \mathrm{SiO}_{2}$ ratio were higher than those of the hydrophobic silica aerogel.

A schematic illustration of the proposed carbothermal reduction reaction mechanism for silica aerogels is shown in Figure 7. The surface of the hydrophobic silica aerogel was modified to contain methyl groups. During the carbothermal reduction of the aerogel, the C-H bonds were broken, whereas the tetrahedral environments of silicon and carbon were maintained. It can be inferred that amorphous hydrogenated $\mathrm{SiC}$ or hydrogenated $\mathrm{Si}-\mathrm{C}-\mathrm{O}$ (silicon oxycarbide) has a cristobalite form at temperatures between 1000 and $1400{ }^{\circ} \mathrm{C}$ [38]. During this process, condensation reactions between $-\mathrm{Si}\left(\mathrm{CH}_{3}\right)_{3}$ and neighboring $-\mathrm{Si}\left(\mathrm{CH}_{3}\right)_{3}$ groups occur, which lead to the formation of $\mathrm{CH}_{4}$ and $\mathrm{H}_{2}$ from the consumed $\mathrm{CH}_{3}$ groups [39]. Above $1400{ }^{\circ} \mathrm{C}, \mathrm{SiC}$ particles nucleate and grow toward the inside of the silica aerogel particles via a gas-phase reaction between $\mathrm{SiO}$ and $\mathrm{CO}$, as has typically been observed for the carbothermal reduction of silica. It appears that the surface methyl groups not only act as the carbon source but also serve as a template for the formation of the SiC particles [40-42]. As observed in Figures 6 and 7, the $\mathrm{SiC}$ particles maintained the spherical morphology of the silica aerogel powder.

Figure 8 shows the SEM images of the silica aerogel and $\beta-\mathrm{SiC}$ powders synthesized from the $\mathrm{SiO}_{2}-\mathrm{C}$ mixtures at various reduction temperatures. The $\mathrm{C} / \mathrm{SiO}_{2}$ ratio was 0.5. Based on Figure 8a, the starting silica aerogel had spherical morphology and significant aggregation cannot be observed. The particle size was estimated to be 5 to $10 \mu \mathrm{m}$. An interesting feature can be observed in Figure 8b-e, that is, the synthesized $\beta$-SiC powders exhibit spherical morphology, regardless of the reduction temperature. 


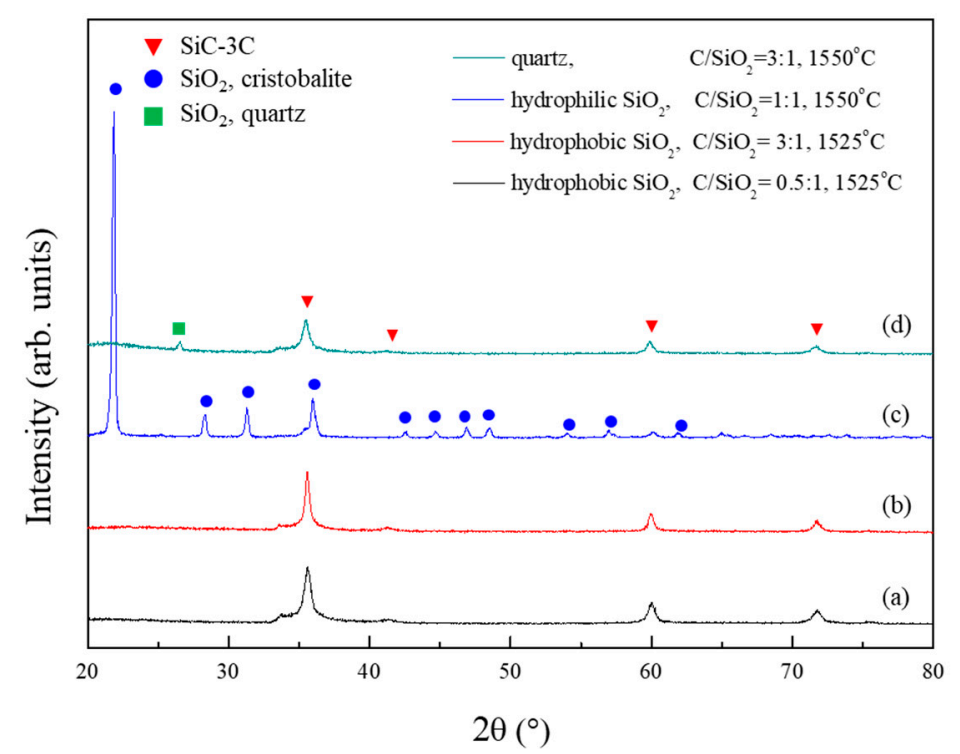

Figure 6. XRD patterns of the powder samples synthesized from (a) the hydrophobic silica aerogel $\left(\mathrm{C} / \mathrm{SiO}_{2}\right.$ ratio of 0.5$),(\mathbf{b})$ the hydrophobic silica aerogel $\left(\mathrm{C} / \mathrm{SiO}_{2}\right.$ ratio of 3), (c) the hydrophilic silica aerogel $\left(\mathrm{C} / \mathrm{SiO}_{2}\right.$ ratio of 1$)$, and $(\mathbf{d})$ the quartz $\left(\mathrm{C} / \mathrm{SiO}_{2}\right.$ ratio of 3$)$.<smiles>CO[Si](OC)(OC)O[Si]1(O[Si](C)(C)C)O[Si](C)(C)CC[Si](O[Si](C)(C)C)(O[Si](C)(C)C)O1</smiles>

Silica aerogel

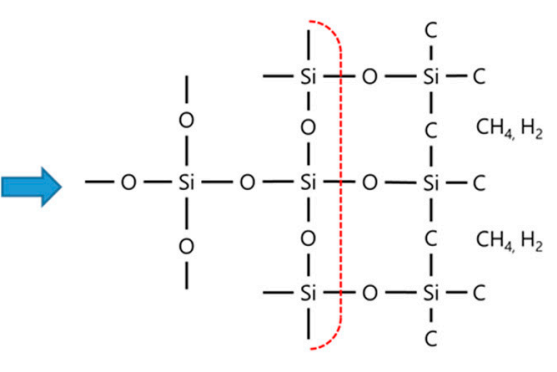

Condensation between surface $-\left(\mathrm{CH}_{3}\right)_{3}$ groups<smiles></smiles>

$\mathrm{SiC}$ formation

Figure 7. Surface structure of the hydrophobic silica aerogel used in this study.

The particle size and morphology of the $\mathrm{SiC}$ powder samples obtained at different $\mathrm{C} / \mathrm{SiO}_{2}$ ratios were analyzed using SEM. Figure 9 shows the SEM images of the $\beta$-SiC powders synthesized from $\mathrm{SiO}_{2}-\mathrm{C}$ mixtures with $\mathrm{C} / \mathrm{SiO}_{2}$ ratios of 0.5 and 3. The carbothermal reduction was performed at $1525^{\circ} \mathrm{C}$ for $1 \mathrm{~h}$. The comparison of Figure 9a,b shows that the morphology of the $\mathrm{SiC}$ particles was completely different. At a C/SiO 2 ratio of 0.5 , the $\mathrm{SiC}$ particles were spherical. By contrast, a high $\mathrm{C} / \mathrm{SiO}_{2}$ ratio of 3 yielded an agglomerated structure consisting of fine $\mathrm{SiC}$ particles. In addition, nanofiber-like $\mathrm{SiC}$ was observed between the fine $\mathrm{SiC}$ particles. The BET specific surface areas of the $\mathrm{SiC}$ powders prepared using $\mathrm{C} / \mathrm{SiO}_{2}$ ratios of 1 and 3 were estimated to be 6.4 and $12.7 \mathrm{~m}^{2} / \mathrm{g}$, respectively. This shows that the specific surface areas increase with the $\mathrm{C} / \mathrm{SiO}_{2}$ ratio. These results suggest that the $\mathrm{C} / \mathrm{SiO}_{2}$ ratio affects the nucleation and growth mechanisms during the synthesis of $\mathrm{SiC}$ powder.

To elucidate the effect of the porous structure of the $\mathrm{SiC}$ on oxidation, the oxygen content in the $\mathrm{SiC}$ powder samples was determined using an oxygen-nitrogen analyzer. The oxygen contents in the $\mathrm{SiC}$ powder prepared at $1525^{\circ} \mathrm{C}$ for $5 \mathrm{~h}$ with $\mathrm{C} / \mathrm{SiO}_{2}$ ratios of 0.5 and 3 were 0.36 and $0.05 \mathrm{wt} . \%$ for the samples after the heat treatment in air, respectively. Almost-pure $\mathrm{SiC}$ powders were obtained when the $\mathrm{C} / \mathrm{SiO}_{2}$ ratio was 3 . 

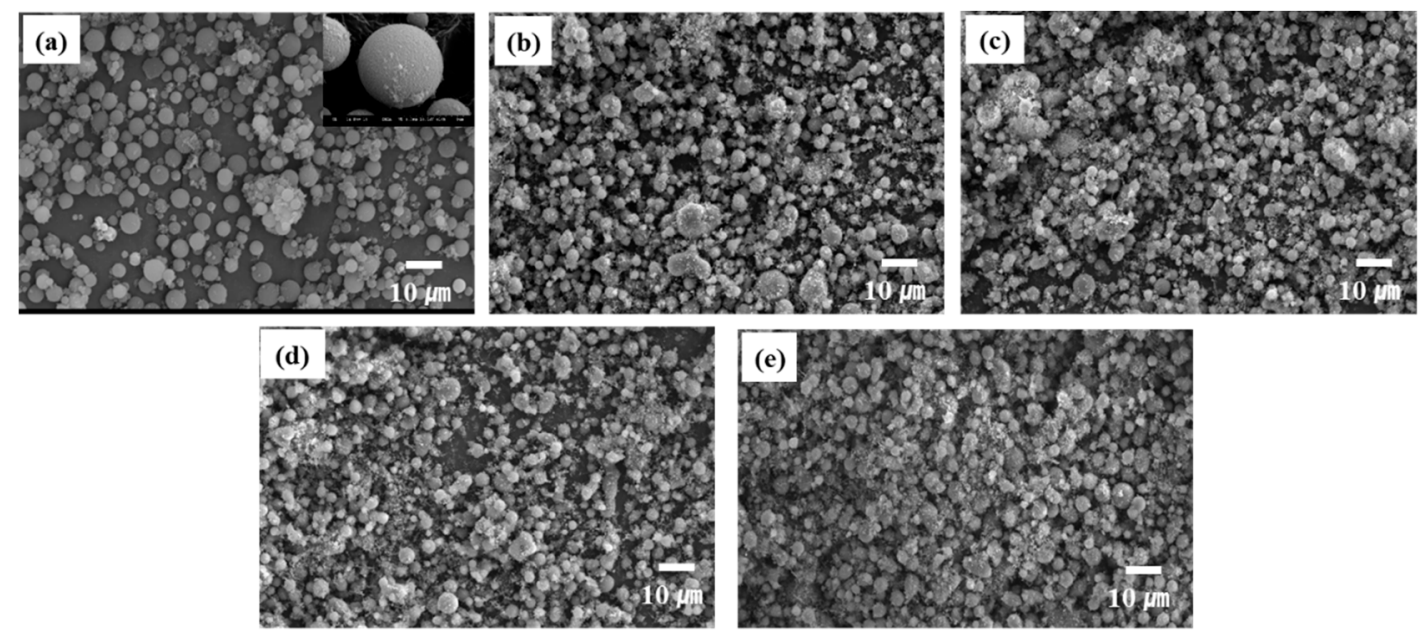

Figure 8. SEM images of (a) the starting spherical silica aerogel and b-SiC powders synthesized from the $\mathrm{SiO}_{2}-\mathrm{C}$ mixtures at (b) $1450{ }^{\circ} \mathrm{C}$, (c) $1475{ }^{\circ} \mathrm{C}$, (d) $1500{ }^{\circ} \mathrm{C}$, and (e) $1525^{\circ} \mathrm{C}$ for $3 \mathrm{~h}$. The $\mathrm{C} / \mathrm{SiO}_{2}$ ratio was 0.5 .
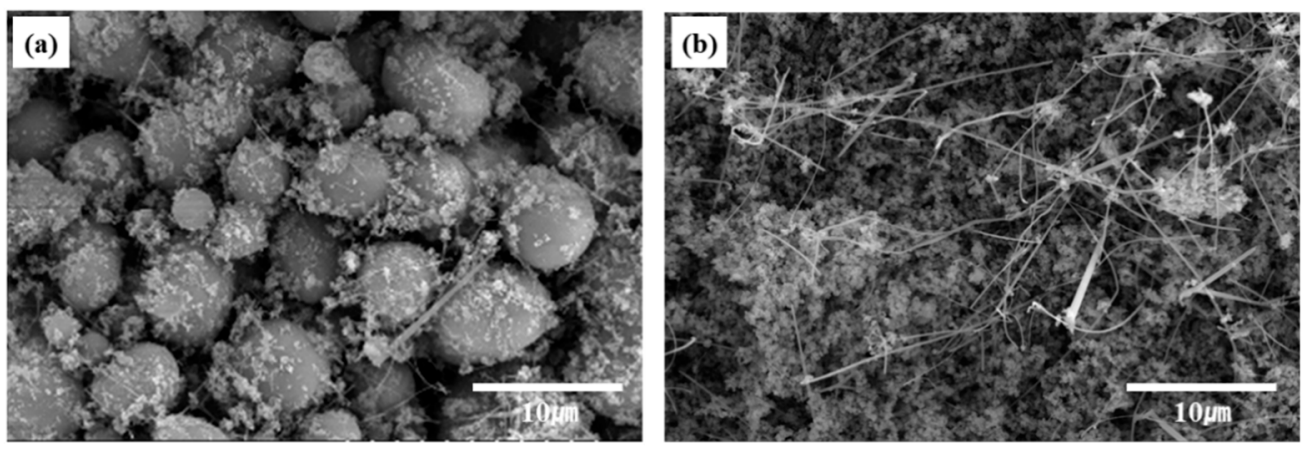

Figure 9. $\mathrm{SEM}$ images of the $\mathrm{SiC}$ powders synthesized from $\mathrm{SiO}_{2}-\mathrm{C}$ mixtures with $\mathrm{C} / \mathrm{SiO}_{2}$ ratios of (a) 0.5 and (b) 3 at $1525^{\circ} \mathrm{C}$ for $1 \mathrm{~h}$. The powder samples were heat-treated in air at $1000{ }^{\circ} \mathrm{C}$ for $1 \mathrm{~h}$ after reduction.

The overall carbothermal reduction reaction for silica, which is a solid $\left(\mathrm{SiO}_{2}\right)$-solid $(\mathrm{C})$ reaction, is shown in Equation (1). At low temperature, the carbothermal reduction reaction can be written in as follows [43]:

$$
\begin{aligned}
& \mathrm{SiO}_{2}(\mathrm{~s})+\mathrm{C}(\mathrm{s}) \rightarrow \mathrm{SiO}(\mathrm{g})+\mathrm{CO}(\mathrm{g}) \\
& \mathrm{SiO}(\mathrm{g})+2 \mathrm{C}(\mathrm{s}) \rightarrow \mathrm{SiC}(\mathrm{s})+\mathrm{CO}(\mathrm{g})
\end{aligned}
$$

At a high temperature and high $\mathrm{P}_{\mathrm{SiO}} / \mathrm{P}_{\mathrm{CO}}$ ratio, whisker- or nanofiber-like $\mathrm{SiC}$ can be grown on the SiC nuclei based on Equation (4), which is similar to the CVD of SiC [35,44]. The SiC particles obtained through Equation (3) serve as nucleation sites for Equation (4).

$$
\mathrm{SiO}(\mathrm{g})+3 \mathrm{CO}(\mathrm{g}) \rightarrow \mathrm{SiC}(\mathrm{s})+2 \mathrm{CO}_{2}(\mathrm{~g})
$$

The morphologies of the $\mathrm{SiC}$ particles differ, as shown in Figure $9 \mathrm{a}, \mathrm{b}$, which indicates that the formation mechanisms for the $\mathrm{SiC}$ particles differ. At a $\mathrm{C} / \mathrm{SiO}_{2}$ ratio of 0.5 , the morphologies of the synthesized $\mathrm{SiC}$ particles are similar to that of the starting silica aerogel, suggesting that the $\mathrm{SiC}$ formation mechanism relies on Equation (1), that is, the solid-solid reaction. The solid $\mathrm{SiO}_{2}$ particles directly react with carbon from the surface methyl groups, whereby spherical $\mathrm{SiC}$ powder was observed at a $\mathrm{C} / \mathrm{SiO}_{2}$ ratio of 0.5 .

The molar ratio of carbon in the $\mathrm{SiO}_{2}-\mathrm{C}$ mixture is of great importance because the $\mathrm{CO}$ gas that is produced by Equations (1) or (2) was sufficiently supplied. The high $\mathrm{C} / \mathrm{SiO}_{2}$ ratio (3) leads to an 
increase in the partial pressure of gaseous species, such as $\mathrm{SiO}(\mathrm{g})$ and $\mathrm{CO}(\mathrm{g})$; consequently, $\mathrm{SiC}$ particles form and grow, as illustrated in Equations (3) and (4). The nanofiber-like SiC observed in Figure 9b might be due to the reaction expressed in Equation (4).

\section{Conclusions}

$\beta$-SiC powders were synthesized by the carbothermal reduction of methyl-bearing surface-modified silica aerogel/carbon mixtures. Based on the XRD analysis, single-phase $\beta$-SiC was synthesized at $1525^{\circ} \mathrm{C}$ from the silica aerogel/carbon mixture with a $\mathrm{C} / \mathrm{SiO}_{2}$ ratio of 3 . The surface methyl groups that are covalently bonded to the silica aerogel serve as a carbon source for the carbothermal reduction reaction; therefore, the formation temperature for $\mathrm{SiC}$ is lower. The direct bond between silicon and carbon atoms in the surface methyl group results in the enhanced kinetics of the carbothermal reduction reaction. The results show that the $\mathrm{C} / \mathrm{SiO}_{2}$ ratio plays an important role in both the reduction of the formation temperature for $\mathrm{SiC}$ and the control of the morphology of the synthesized $\mathrm{SiC}$ particles. At a $\mathrm{C} / \mathrm{SiO}_{2}$ ratio of $0.5, \mathrm{SiC}$ maintains the original spherical morphology of the silica aerogels. By contrast, agglomerates with fine $\mathrm{SiC}$ particles were synthesized from the $\mathrm{SiO}_{2}-\mathrm{C}$ mixture at a $\mathrm{C} / \mathrm{SiO}_{2}$ ratio of 3 . This phenomenon can be attributed to different formation mechanisms for $\mathrm{SiC}$, which depend on the silica-carbon ratio of the starting silica/carbon mixture. Almost pure $\mathrm{SiC}$ powder $(99.95 \%)$ was obtained when the silica aerogel/carbon mixture at a $\mathrm{C} / \mathrm{SiO}_{2}$ ratio of 3 was reduced at $1525^{\circ} \mathrm{C}$ for $5 \mathrm{~h}$.

Author Contributions: Conceptualization, K.-J.L. and H.H.; methodology, Y.K., Y.H.K. and S.W.B.; analysis, K.-J.L., Y.K. and Y.H.K.; writing-original draft preparation, K.-J.L. writing_review and editing, H.H.; supervision, H.H.; project administration, H.H. and S.W.B. All authors have read and agreed to the published version of the manuscript.

Funding: This work was supported by LG Chem. This research was supported by the Ministry of Trade, Industry \& Energy (MOTIE), Korea Institute for Advancement of Technology (KIAT), through the Encouragement Program for The Industries of Economic Cooperation Region (P0002149).

Conflicts of Interest: The authors declare no conflict of interest.

\section{References}

1. Shcherban, N.D. Review on synthesis, structure, physical and chemical properties and functional characteristics of porous silicon carbide. J. Ind. Eng. Chem. 2017, 50, 15-28. [CrossRef]

2. Kim, K.; Hahn, Y.; Lee, S.; Choi, K.; Lee, J.-H. Mechanical Properties of $C_{\mathrm{f}} / \mathrm{SiC}$ Composite Using a Combined Process of Chemical Vapor Infiltration and Precursor Infiltration Pyrolysis. J. Korean Ceram. Soc. 2018, 55, 392-399. [CrossRef]

3. Seo, Y.; Kim, Y.; Nishimura, T.; Seo, W.S. High-temperature strength of a thermally conductive silicon carbide ceramic sintered with yttria and scandia. J. Eur. Ceram. Soc. 2016, 36, 3755-3760. [CrossRef]

4. Chen, H.; Wang, X.; Xue, F.; Huang, Y.; Zhou, K.; Zhang, D. 3D printing of SiC ceramic, Direct ink writing with a solution of preceramic polymers. J. Eur. Ceram. Soc. 2018, 38, 5294-5300. [CrossRef]

5. Bernardo, E.; Fiocco, L.; Parcianello, G.; Storti, E.; Colombo, P. Advanced ceramics from preceramic polymers modified at the nano-scale: A review. Materials 2014, 7, 1927-1956. [CrossRef]

6. Prochazka, S.; Scanlan, R.M. Effect of boron and carbon on sintering of SiC. J. Am. Ceram. Soc. 1975, 58, 72. [CrossRef]

7. Syväjärvi, M.; Ma, Q.; Jokubavicius, V.; Galeckas, A.; Sun, J.; Liu, X.; Jansson, M.; Wellmann, P.; Linnarsson, M.; Runde, P.; et al. Cubic silicon carbide as a potential photovoltaic material. Sol. Energy Mater. Sol. Cells 2016, 145, 104-108. [CrossRef]

8. Kim, J.G.; Jeong, J.H.; Kim, Y.; Makarov, Y.; Choi, D.J. Evaluation of the change in properties caused by axial and radial temperature gradients in silicon carbide crystal growth using the physical vapor transport method. Acta Mater. 2014, 77, 54-59. [CrossRef]

9. Sciti, D.; Bellosi, A. Effects of additives on densification, microstructure and properties of liquid-phase sintered silicon carbide. J. Mater. Sci. 2000, 35, 3849-3855. [CrossRef] 
10. Wang, X.; Cai, D.; Zhang, H. Increase of SiC sublimation growth rate by optimizing of powder packaging. J. Cryst. Growth 2007, 305, 122-132. [CrossRef]

11. Hayun, S.; Paris, V.; Mitrani, R.; Kalabukhov, S.; Dariel, M.P.; Zaretsky, E.; Frage, N. Microstructure and mechanical properties of silicon carbide processed by Spark Plasma Sintering (SPS). Ceram. Int. 2012, 38, 6335-6340. [CrossRef]

12. Kim, J.G.; Jung, E.J.; Kim, Y.; Makarov, Y.; Choi, D.J. Quality improvement of single crystal $4 \mathrm{H} \mathrm{SiC}$ grown with a purified $\beta$-SiC powder source. Ceram. Int. 2014, 40, 3953-3959. [CrossRef]

13. Omidi, Z.; Ghasemi, A.; Bakhshi, S.R. Synthesis and characterization of SiC ultrafine particles by means of sol-gel and carbothermal reduction methods. Ceram. Int. 2015, 41, 5779-5784. [CrossRef]

14. Barbouche, M.; Zaghouani, R.B.; Benammar, N.E.; Khirouni, K.; Ezzaouia, H. Synthesis and characterization of 3C-SiC by rapid silica carbothermal reduction. Int. J. Adv. Manuf. Technol. 2017, 91, 1339-1345. [CrossRef]

15. Kim, J.; Choi, S.; Kim, J.; Choi, S.C. Characteristics of silicon carbide nanowires synthesized on porous body by carbothermal reduction. J. Korean Ceram. Soc. 2018, 55, 285-289. [CrossRef]

16. Kwon, W.T.; Kim, S.R.; Kim, Y.; Lee, Y.J.; Won, J.Y.; Park, W.K.; Oh, S.C. Effect of temperature and carbon contents on the synthesis of $\beta-\mathrm{SiC}$ from silicon sludge by direct carbonization method. Mater Sci. Forum. 2012, 724, 45-48. [CrossRef]

17. Yang, Y.; Lin, Z.; Li, J. Synthesis of SiC by silicon and carbon combustion in air. J. Eur. Ceram. Soc. 2009, 29, 175-180. [CrossRef]

18. Colombo, P.; Mera, G.; Riedel, R.; Soraru, G.D. Polymer-derived ceramics: 40 years of research and innovation in advanced ceramics. J. Am. Ceram. Soc. 2010, 93, 1805-1837. [CrossRef]

19. Andrievski, R.A. Synthesis, structure and properties of nanosized silicon carbide. Rev. Adv. Mater Sci. 2009, 22, 1-20.

20. Yazdanfar, M.; Pedersen, H.; Sukkaew, P.; Ivanov, I.G.; Danielsson, Ö.; Kordina, O.; Janzén, E. On the use of methane as a carbon precursor in Chemical Vapor Deposition of silicon carbide. J. Cryst. Growth 2014, 390, 24-29. [CrossRef]

21. Galvagno, S.; Portofino, S.; Casciaro, G.; Casu, S.; d'Aquino, L.; Martino, M.; Russo, A.; Bezzi, G. Synthesis of beta silicon carbide powders from biomass gasification residue. J. Mater. Sci. 2007, 42, 6878-6886. [CrossRef]

22. Kevorkijan, V.M.; Komac, M.; Kolar, D. Low-temperature synthesis of sinterable SiC powders by carbothermic reduction of colloidal $\mathrm{SiO}_{2}$. J. Mater. Sci. 1992, 27, 2705-2712. [CrossRef]

23. Bağci, C.; Arik, H. Synthesis of SiC Powders by carbothermal reduction of enriched brown sepiolite with carbon black. J. Mater. Eng. Perform. 2013, 22, 958-963. [CrossRef]

24. Shimoo, T. Carbon removal and oxidation of $\mathrm{SiC}$ powder synthesized by carbothermic reduction of silica. J. Ceram Soc. Jpn. 1991, 99, 768-773. [CrossRef]

25. Parmentier, J.; Patarin, J.; Dentzer, J.; Vix-Guterl, C. Formation of SiC via carbothermal reduction of a carbon-containing mesoporous MCM-48 silica phase: A new route to produce high surface area SiC. Ceram. Int. 2002, 28, 1-7. [CrossRef]

26. Meng, G.W.; Cui, Z.; Zhang, L.D.; Phillipp, F. Growth and characterization of nanostructured $\beta$-SiC via carbothermal reduction of $\mathrm{SiO}_{2}$ xerogels containing carbon nanoparticles. J. Cryst. Growth 2000, 209, 801-806. [CrossRef]

27. Lee, K.; Kim, Y.H.; Lee, J.K.; Hwang, H.J. Fast synthesis of spherical silica aerogel powders by emulsion polymerization from water glass. ChemistrySelect 2018, 3, 1257-1261. [CrossRef]

28. Sarawade, P.B.; Kim, J.K.; Hilonga, A.; Quang, D.V.; Jeon, S.J.; Kim, H.T. Synthesis of sodium silicate-based hydrophilic silica aerogel beads with superior properties: Effect of heat-treatment. J. Non-Cryst. Solids 2011, 357, 2156-2162. [CrossRef]

29. Bhagat, S.D.; Kim, Y.H.; Suh, K.H.; Ahn, Y.S.; Yeo, J.G.; Han, J.H. Superhydrophobic silica aerogel powders with simultaneous surface modification, solvent exchange and sodium ion removal from hydrogels. Microporous Mesoporous Mater. 2008, 112, 504-509. [CrossRef]

30. Rao, A.P.; Rao, A.V.; Pajonk, G.M. Hydrophobic and physical properties of the two step processed ambient pressure dried silica aerogels with various exchanging solvents. J. Sol-Gel Sci. Technol. 2005, 36, 285-292. [CrossRef]

31. He, S.; Huang, Y.; Ghen, G.; Feng, M.; Dai, H.; Yuan, B.; Chen, X. Effect of heat treatment on hydrophobic silica aerogel. J. Hazard. Mater. 2019, 362, 294-302. [CrossRef] [PubMed] 
32. Shao, Z.D.; Cheng, X.; Zheng, Y.M. Facile co-precursor sol-gel synthesis of a novel amine-modified silica aerogel for high efficiency carbon dioxide capture. J. Colloid Interface Sci. 2018, 530, 412-423. [CrossRef] [PubMed]

33. Stojanovic, A.; Zhao, S.; Angelica, E.; Malfait, W.J.; Koebel, M.M. Three routes to superinsulating silica aerogel powder. J. Sol-Gel Sci. Technol. 2019, 90, 57-66. [CrossRef]

34. Bhagat, S.D.; Oh, C.; Kim, Y.; Ahn, Y.S.; Yeo, J.G. Methyltrimethoxysilane based monolithic silica aerogels via ambient pressure drying. Microporous Mesoporous Mater. 2007, 100, 350-355. [CrossRef]

35. Jeong, S.; Seo, W.; Jung, I.; Lee, K.J.; Hwang, H.J. Thermodynamic analysis of the synthesis of silicon carbide nanofibers from exfoliated graphite and amorphous silica. CrystEngComm 2014, 16, 2348-2351. [CrossRef]

36. Choi, H.; Lee, J. Continuous synthesis of silicon carbide whiskers. J. Mater. Sci. 1995, 30, $1982-1986$. [CrossRef]

37. Eichhammer, Y.; Roeck, J.; Moelans, N.; Iacopi, F.; Blanpain, B.; Heyns, M. Calculation of the Au-Ge phase diagram for nanoparticles. Arch. Metall. Mater. 2008, 53, 1133-1139.

38. Bouillon, E.; Langlais, F.; Pailler, R.; Naslain, R.; Cruege, F.; Huong, P.V.; Sarthou, J.C.; Delpuech, A.; Laffon, C.; Lagarde, P.; et al. Conversion mechanisms of a polycarbosilane precursor into an SiC-based ceramic material. J. Mater. Sci. 1991, 26, 1333-1345. [CrossRef]

39. Soraru, G.D.; Babonneau, F.; Mackenzie, J.D. Structural evolutions from polycarbosilane to SiC ceramic. J. Mater. Sci. 1990, 25, 3886-3893. [CrossRef]

40. Xie, W.; Möbus, G.; Zhang, S. Molten salt synthesis of silicon carbide nanorods using carbon nanotubes as templates. J. Mater. Chem. 2011, 21, 18325-18330. [CrossRef]

41. Wu, Y.J.; Qin, W.; Yang, Z.X.; Wu, J.S.; Zhang, Y.F. Preparation of high-quality ß-SiC nanowhiskers by using carbon fibres as carbon source. J. Mater. Sci. 2004, 39, 5563-5565. [CrossRef]

42. Tony, V.; Voon, C.H.; Lee, C.C.; Lim, B.Y.; Arshad, M.M.; Gopinath, S.C.; Foo, K.L.; Ruslinda, A.R.; Hashim, U.; Nashaain, M.N. Novel synthesis of silicon carbide nanotubes by microwave heating of blended silicon dioxide and multi-walled carbon nanotubes: The effect of the heating temperature. Ceram. Int. 2016, 42, 17642-17649. [CrossRef]

43. Van Dijen, F.K.; Metselaar, R. The chemistry of the carbothermal synthesis of $\beta$-SiC: Reaction mechanism, reaction rate and grain growth. J. Eur. Ceram. Soc. 1991, 7, 177-184. [CrossRef]

44. Moshtaghioun, B.M.; Poyato, R.; Cumbrera, F.L.; de Bernardi-Martin, S.; Monshi, A.; Abbasi, M.H.; Karimzadeh, F.; Dominguez-Rodriguez, A. Rapid carbothermic synthesis of silicon carbide nano powders by using microwave heating. J. Eur. Ceram. Soc. 2012, 32, 1787-1794. [CrossRef] 